\title{
HYDRAULIC ASSESSMENT OF THE IMPACTS OF GATE REALIZATION ON GROUNDWATER REGIME
}

\author{
${ }^{1}$ Andrej ŠOLTÉSZ, ${ }^{2}$ Dana BAROKOVÁ, ${ }^{3}$ Zinaw Dingetu SHENGA ${ }^{*}$ \\ ${ }^{4}$ Michaela ČERVEŇANSKÁ \\ 1,2,3,4 Department of Hydraulic Engineering, Faculty of Civil Engineering \\ Slovak University of Technology in Bratislava, e-mail: ${ }^{1}$ andrej.soltesz@stuba.sk \\ 2dana.barokova@stuba.sk, ${ }^{3}$ zinaw.shenga@stuba.sk \\ ${ }^{4}$ michaela.cervenanska@stuba.sk
}

Received 31 December 2019; accepted 27 March 2020

\begin{abstract}
Presented paper deals with the hydraulic assessment of groundwater flow in the area affected by the realization of the hydraulic gate on the Klatov branch and in the adjacent territory of a dike, which is located on the right-side of Little Danube. This hydraulic assessment is part of the project of the Slovak Water Management Enterprise, which also aims to increase the height and seal the dike on the right-side of the Little Danube. Generally, the project is divided into three phases (Phase I, II and III) to implement different technical measures to protect the area from flooding. The assumption for the execution of the technical measures of the mentioned three project phases is a continuous flood protection of part of the Žitný ostrov area around the Little Danube and the Klátov River branch in the reach from Kolárovo to Jahodná town. Therefore, a 3D mathematical model was created to simulate groundwater flow by changing boundary conditions of surface water flow during flood periods.
\end{abstract}

Keywords: Hydraulic assessment, Klátov River branch, Hydraulic gate, Numerical simulation, Flood protection dike

\section{Introduction}

Increasing the flood protection of the right-side of the Little Danube was an impulse for the elaboration of the project, 'Increasing the safety of the territory against the backflow of the Little Danube and Klátov River branch of Danube and Váh River', from the workshop of Slovak Water Management Enterprise, s. e. Bratislava [1]. Several technical measures, which are divided into three phases, should be implemented

\footnotetext{
${ }^{*}$ Corresponding Author
} 
in order to protect the territory from flooding [2]. In the first phase of the project, a closure structure (hydraulic gate) on Klatov branch is designed along with the construction of a transverse dike and its connection to the existing right-side dike of the Little Danube and Klátov branch. In the second phase, modification of existing rightside dike on the Little Danube is designed. This phase is planned to be implemented in two stages. The first stage of second phase covers modification of right-side dike on Little Danube, which extends $4.960 \mathrm{~km}$ from the section of Asód to Topol'níky village and $2.125 \mathrm{~km}$ from section of Topol'níky to Trhová Hradská village. The second stage of the second phase covers further modification of right-side dike on the Little Danube, which extends $8.514 \mathrm{~km}$ from section of Trhová Hradská to Horné Mýto village. In the third phase of the project, a similar modification, which extends about $10.990 \mathrm{~km}$ is proposed for the section from Kolárovo village to pump station of Asód. A schematic representation of the above technical measures is shown in Fig. 1.

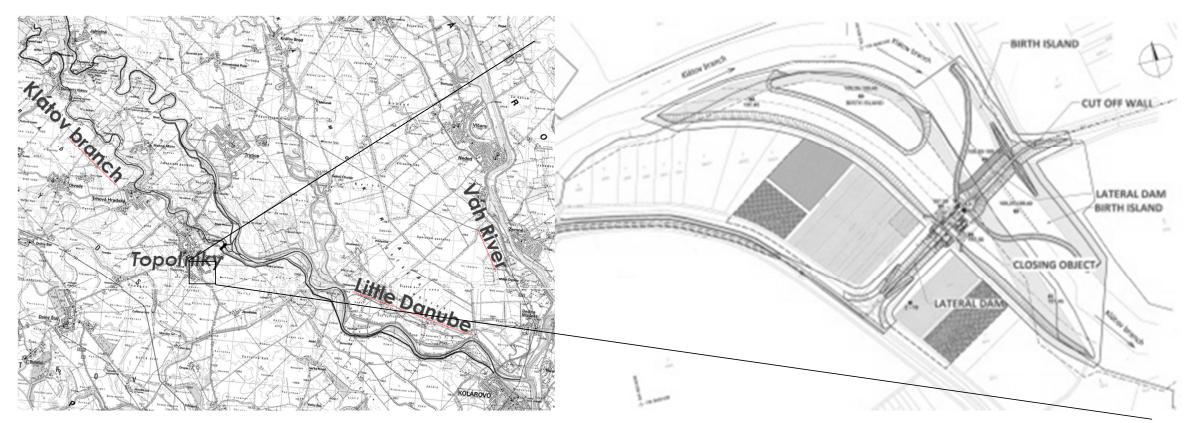

Fig. 1. Location of proposed hydraulic gate after Phase III of the project with details of the gate on Klátov branch at Topol'níky village,

(The System of the Unified Czech/Slovak Trigonometric Cadastral Network (S-JTSK): $(Y, X)=$ from 524200,1305000 to 523800,1304600

In Fig. 1, the right part detail shows the location of the gate structure, which according to the project is situated on the Klátov branch in between the dike area on the right-side of the Little Danube. The designed gate structure will be kept open under normal operating condition and it is designed to allow gravitational flow of water from the Klátov branch to the Little Danube. However, during flood period, i.e. after reaching flood level of $110.90 \mathrm{~m}$ a.s.l., the water starts to drain, and the gate closes gradually. After the water level reaches $111.30 \mathrm{~m}$ a.s.l., water from the Klátov branch should be pumped to Little Danube and the water level in Klátov branch immediately before the gate will be maintained at elevation of $110.90 \mathrm{~m}$ a.s.l. [1].

The modification of the existing right-side dike of the Little Danube consists of sealing it and increasing the dike height to a level of $114.00 \mathrm{~m}$ a.s.l. The existence of privileged seepage routes in certain sections of the right-side dike and the related phenomenon observed during the floods have led to the need to extend the seepage path and seal the subsoil layer located under the dike [3]. As the impermeable layer is located too deep under the terrain, it is advisable to extend the seepage path with help of a vertical sealing element (a suspended underground sealing wall), which intersects the 
permeable layers located under the dike. Due to high horizontal permeability in this area, some grain materials float with the flood and reduce the resistance of the dike.

Additionally, the project includes assessments of the impacts of the proposed technical measures on the groundwater regime at normal flow condition as well as during flood period in the Little Danube. Therefore, the main goal of this paper is to predict the change in groundwater flow and also compare the groundwater regime before and after construction of the gate structure.

\section{Input data and method}

TRIWACO, an integrated modeling environment [4] was used to carry out a numerical simulation of groundwater flow to study the impacts of the proposed technical flood protection measures on the groundwater regime. It is a computer-based program to run quasi three-dimensional groundwater flow based on the finite element method [4]. It has capability to simulate both steady and transient groundwater flow in different aquifer systems [4]. It is designed to translate and process standard input data to input files of certain model codes [4].

As the accuracy of groundwater simulation depends on the quality and quantity of input data [5], it was necessary to obtain different input data to develop the conceptual model. Analysis of the current situation, calibration of the model and prediction of the development of groundwater after implementation of the planned structure highly depends on the quality of the input data [6], [7].

\subsection{Hydrological data}

Information about groundwater and surface water was used for mathematical simulation of groundwater flow. The observed long-term average piezometric groundwater level in the observation boreholes were obtained from Slovak HydroMeteorological Institute (SHMI) [8]. However, the temporal development of piezometric groundwater level in SHMI boreholes was obtained for 2006 flood wave (see Fig. 2).

A different flow scenario data in the Little Danube and Klátov River branch was obtained from Danish Hydraulic Institute (DHI) [9] and used to create a 2D mathematical model for simulation of the area influenced by the surface water. For both groundwater and surface water, the time course of the flood wave in the Little Danube at the turn of March-April 2006 was used.

The time course of the flood wave at different profile in Little Danube is shown in Fig. 2. The selected water levels for different flow scenarios in the Little Danube are shown in Table I and Table II. The water level in the Little Danube for simulated scenarios in Table I and Table II for the section starting at the confluence of the Little Danube and with direct connection to the water level of Váh River (river kilometer (rkm) Little Danube 0.00) to the Jahodná - bridge profile (rkm 42.25) are shown in Fig. 3. 


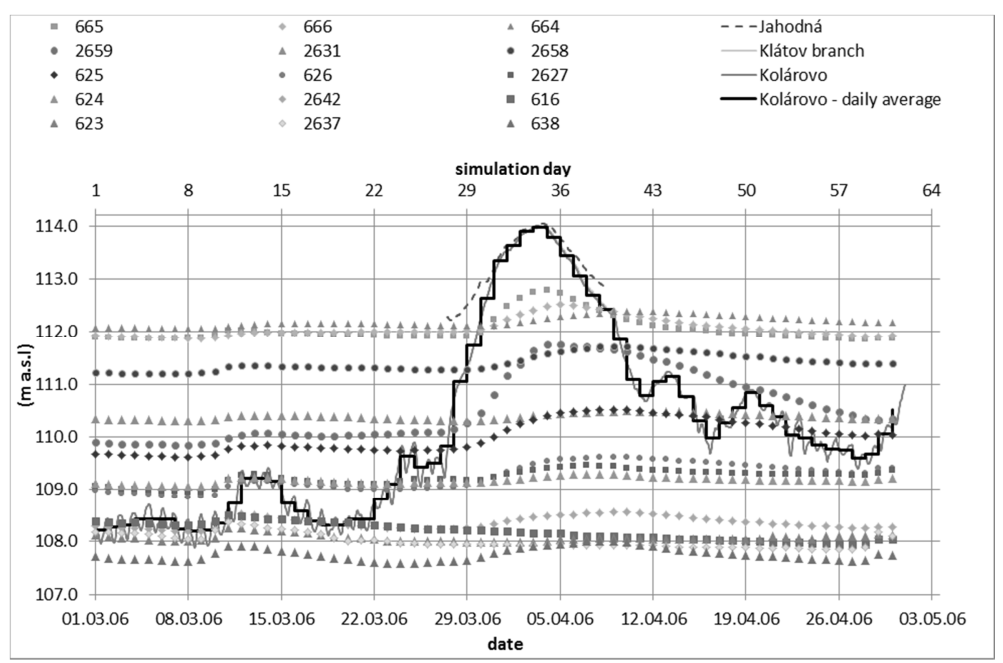

Fig. 2. Temporal development of piezometric groundwater levels in SHMI boreholes together with the time course of simulated design flood wave on the Little Danube River in 2006

Table I

Simulated scenarios for different discharges in Little Danube River (DHI, 2018 a)

\begin{tabular}{|l|l|l|l|l|}
\hline $\begin{array}{l}\text { Scenario } \\
\text { label }\end{array}$ & $\begin{array}{l}\text { Discharge Q } \\
\text { (Little } \\
\text { Danube) }\end{array}$ & $\begin{array}{l}\text { Discharge Q } \\
\text { (Klátov branch) }\end{array}$ & $\begin{array}{l}\text { Water level at } \\
\text { estuary of Klátov } \\
\text { branch without } \\
\text { back water }\end{array}$ & $\begin{array}{l}\text { Water level in the } \\
\text { Little Danube at } \\
\text { Kolárovo free } \\
\text { outflow }\end{array}$ \\
\hline & {$\left[\mathrm{m}^{3} \cdot \mathrm{s}^{-1}\right]$} & {$\left[\mathrm{m}^{3} \cdot \mathrm{s}^{-1}\right]$} & {$[\mathrm{m}$ a.s.l. $]$} & {$[\mathrm{m}$ a.s.1.] } \\
\hline$h_{20}$ & 20 & 5 & 108.41 & 106.50 \\
$h_{35}$ & 35 & 5 & 108.78 & 107.00 \\
$h_{50}$ & 50 & 5 & 109.15 & 107.35 \\
$h_{69}$ & 69 & 5 & 109.51 & 107.40 \\
\hline
\end{tabular}

Table II

Water level values in the Little Danube River during the flood in 2006 (DHI, 2018 b, d)

( $h_{V H}$ water levels at the beginning of the flood wave, $h_{\mathrm{MAX}}$ - culmination water level)

\begin{tabular}{|l|l|l|l|l|l|}
\hline Label & $\begin{array}{l}\text { Date of } \\
\text { Simulation }\end{array}$ & $\begin{array}{l}\text { Water } \\
\text { level at } \\
\text { Jahodná - } \\
\text { bridge }\end{array}$ & $\begin{array}{l}\text { Water } \\
\text { level at } \\
\text { Trstice } \\
\text { gauge }\end{array}$ & $\begin{array}{l}\text { Water level at } \\
\text { Klástov branch } \\
\text { Estuary(backwater } \\
\text { from Váh River) }\end{array}$ & $\begin{array}{l}\text { Water level in the } \\
\text { Little Danube at } \\
\text { Kolárovo } \\
\text { (backwater from } \\
\text { Váh River) }\end{array}$ \\
\hline & & [m a.s.l.] & [m a.s.l.] & [m a.s.l.] & 111.02 \\
\hline $\begin{array}{l}\text { [m a.s.l.] } \\
h_{\mathrm{MAX}}\end{array}$ & $\begin{array}{l}28.3 .2006 \\
3.42006\end{array}$ & $\begin{array}{l}112.33 \\
113.999\end{array}$ & $\begin{array}{l}111.033 \\
113.956\end{array}$ & $\begin{array}{l}111.02 \\
114.01\end{array}$ & 114.00 \\
\hline
\end{tabular}



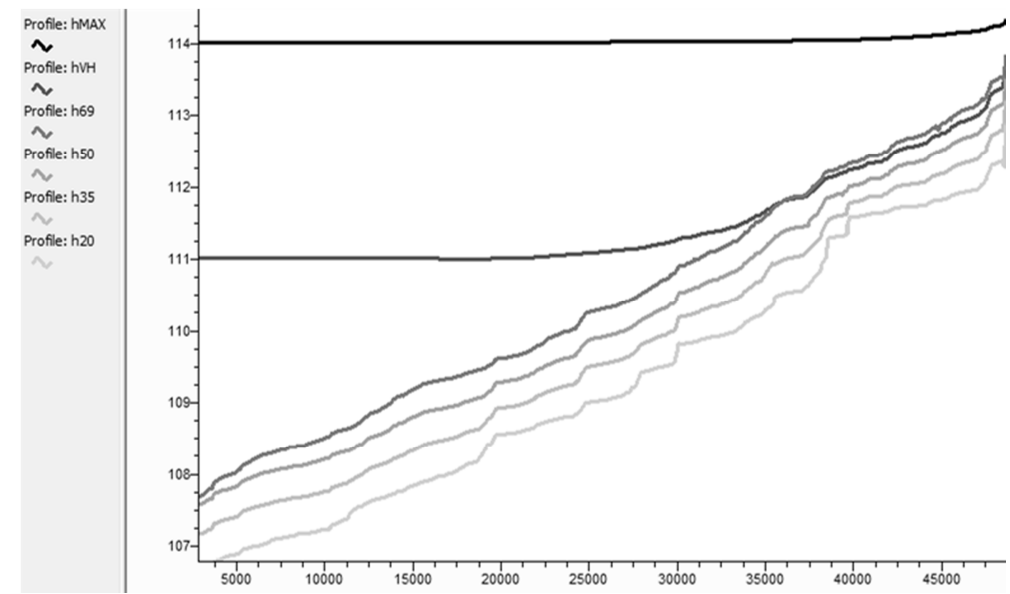

Fig. 3. Water level course (m a.s.1.) in the Little Danube from the confluence with Váh River in at Kolárovo town up to Jahodná - bridge profile according to [9] for different scenarios

\subsection{Hydrogeological data}

The area of interest consists of fluvial quaternary sediments and fine-grained alluvial sands [10], [11]. From lithological point of view, it is a gravel-sand complex with high specific flow $\left(q \geq 1 \times 10^{-2} \mathrm{~m}^{2} \mathrm{~s}^{-1}\right)$. The aquifer with a free surface exceeds a thickness of $100 \mathrm{~m}$ in the area of interest. It is characterized by gravel sediments with high hydraulic conductivity values ranging from $k=1.37 \times 10^{-4} \mathrm{~m} \cdot \mathrm{s}^{-1}$ to $7.5 \times 10^{-3} \mathrm{~m} \cdot \mathrm{s}^{-1}$. From hydrogeological point of view, the area of interest is known by pebble sediments of the Little Danube and the Klátov River branch [9], [12]. The groundwater regime in this area is a result of those sediments and it is influenced by surface water flow and atmospheric precipitation [13]. A research conducted by [14] indicated that groundwater is located at 108.5 to $109.5 \mathrm{~m}$ a.s.1. (i.e. 2.1 to $3.2 \mathrm{~m}$ below the terrain).

\subsection{Topography}

The relief of the area has a flat character and it is divided only by networks of surface water streams. The elevation of the terrain ranges between 112 and $114 \mathrm{~m}$ a.s.l. [15].

\subsection{Method}

In order to achieve the goal of the model (i.e. predicting the development of groundwater and comparing the state before and after the intervention in the natural groundwater regime), it is only possible if the mathematical model is calibrated properly for the current state of the so-called 'normal' steady state and then for the transient state.

The boundary of the model was set based on groundwater water level in SHMI boreholes and inflow to the boundary of the model area. Water level in Little Danube, Klátov branch and Váh River [9] were used as internal boundary condition. On the other 
hand, the observed water level in SHMI boreholes were used for calibration and some of them were used for setting the boundary condition.

For simulation of steady state groundwater flow, the following assumptions were used:

- the water level in the Little Danube is not affected by backwater from Váh River;

- the water level in the Little Danube (h20, h35, h50 and h69) corresponds to the scenarios for flow rate $Q=20,35,50$ and $69 \mathrm{~m}^{3} \cdot \mathrm{s}^{-1}$ (see Table I) and then the scenarios $h_{V H}$ (water level at the beginning of the flood wave) and $h_{\mathrm{MAX}}$ (culminated water level) (see Table II);

- the water level in Klátov branch corresponds to the flow rate $Q=5 \mathrm{~m}^{3} \cdot \mathrm{s}^{-1}$ (see Table I); and

- gate structure at confluence of Little Danube and Klátov branch, which is not constructed yet.

The whole series of simulations were carried out for the proposed variants as defined in the individual project stages [1].

After introducing an initial condition for the steady state flow, transient simulation was carried out based on the following assumptions:

- a flood wave of $Q_{100}$ in Little Danube;

- a flood wave in a Váh River which considers current flow state and prognosis of the gate structure at estuary of Klátov branch when the water level in the Little Danube rises above $111.30 \mathrm{~m}$ a.s.1.

\subsection{Model calibration}

After setting boundary conditions and the compilation of individual scenarios and calculation variants, the created mathematical model is calibrated for steady state flow condition. The calibration was performed for the average annual flow rate in the Little Danube, which is about $35 \mathrm{~m}^{3} \cdot \mathrm{s}^{-1}$ according to. Additionally, the observed average groundwater level in SHMI boreholes (shown in Fig. 2) was also included for calibration purposes. Isolines of simulated piezometric head of groundwater, i.e, course of hydroisohypse of the model are shown in Fig. 4.

Fig. 5 illustrates the differences between simulated and observed groundwater head as well as the labels (codes) of groundwater observation boreholes of the SHMI. The absolute values of the difference between the observed and simulated groundwater head ranges between 0.00 and $0.07 \mathrm{~m}$ at the vicinity of the gate structure, which is acceptable and, therefore, the mathematical model can be used for further simulation.

\section{Discussion}

The results of simulation variants of steady state groundwater flow in the area of interest [16], proved that the difference in piezometric head after realization of the three phases ranges from $0.00-0.05 \mathrm{~m}$ on the right-side of territory of the Little Danube for 
the scenario $Q=20 \mathrm{~m}^{3} \cdot \mathrm{s}^{-1}$ in the Little Danube. However, for the scenario $Q=69 \mathrm{~m}^{3} \cdot \mathrm{s}^{-1}$ in the Little Danube, the difference in the piezometric head ranges from 0.00 to $0.20 \mathrm{~m}$. As the discharge in the Little Danube is expected to be relatively small, the difference in piezometric head in the area of interest is negligible.

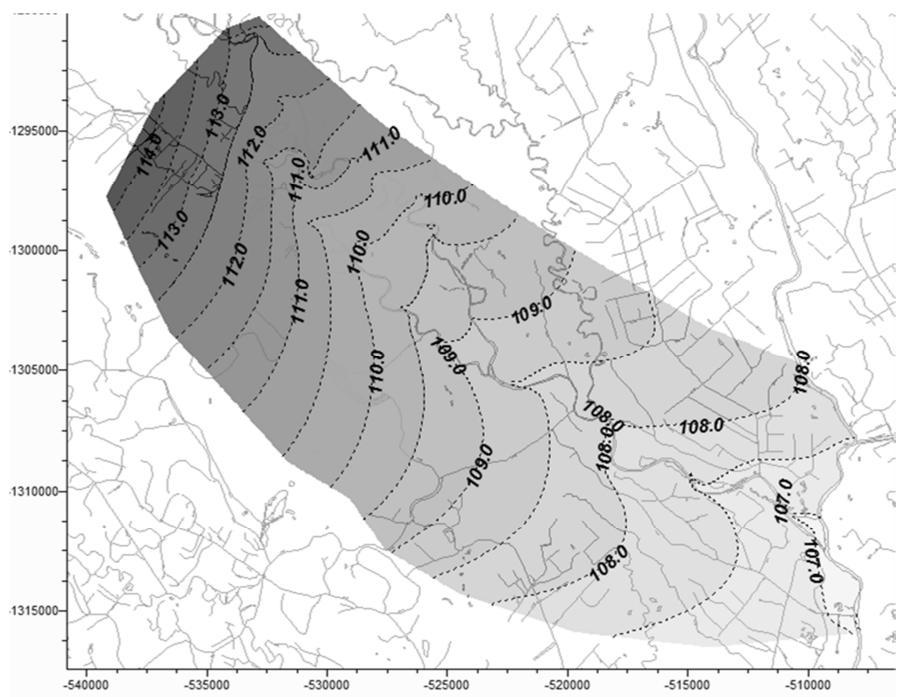

Fig. 4. Illustration of the piezometric heads for $Q=35 \mathrm{~m}^{3} \cdot \mathrm{s}^{-1}$ in the Little Danube River and $Q=5 \mathrm{~m}^{3} \cdot \mathrm{s}^{-1}$ in Klátov branch (without any measures)

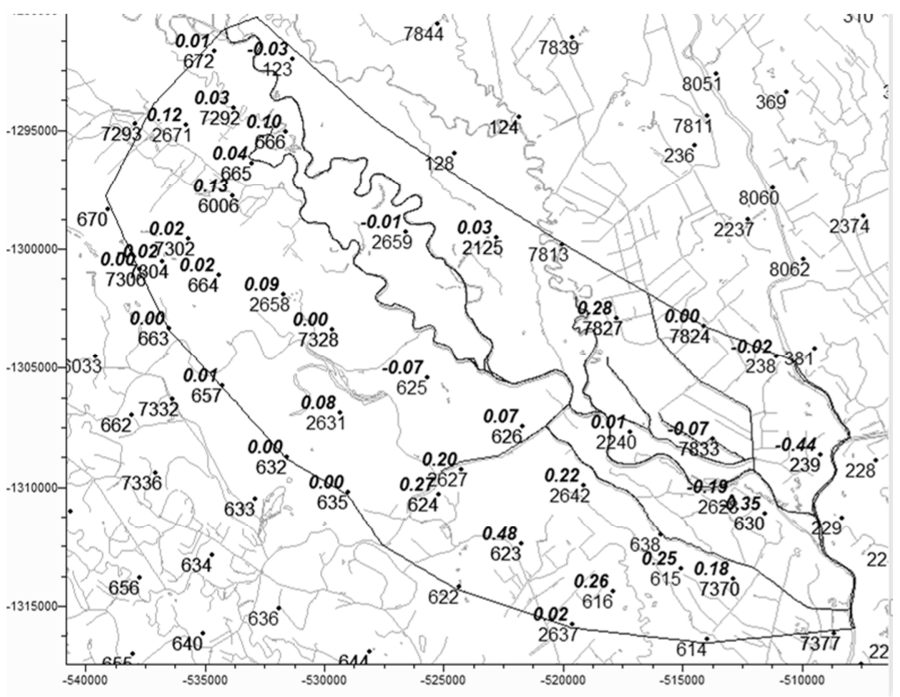

Fig. 5. Illustration of SHMI boreholes after model calibration in the area of interest for steady state condition (difference between calculated and measured values in (m)) 
The transformed flood wave, at selected profiles of Little Danube (see Fig. 2), which was mathematically analyzed by DHI [9] was used as internal boundary condition to run the transient simulation of the groundwater flow. The water level in the Little Danube, Klátov River branch and Váh River was entered at an interval of 1 day to carry out the transient simulation. Additionally, simulated piezometric head corresponding to $Q_{35}$ scenario, i.e. piezometric head that corresponds to water level in the Little Danube at a discharge of $Q=35 \mathrm{~m}^{3} \cdot \mathrm{s}^{-1}$ (see Fig. 3), was used as initial condition to carry out the transient simulation.

The results of this transient simulation are illustrated in Fig. 6 as spatial course of the change in piezometric head before and after the implementation of the planned project. The simulation dates (see Table III) were chosen according to the development of the flood wave in the Little Danube. However, the courses of differences of the piezometric groundwater levels on the $35^{\text {th }}$ day of simulation and observation well OW1-10 marking is shown in Fig. 7.

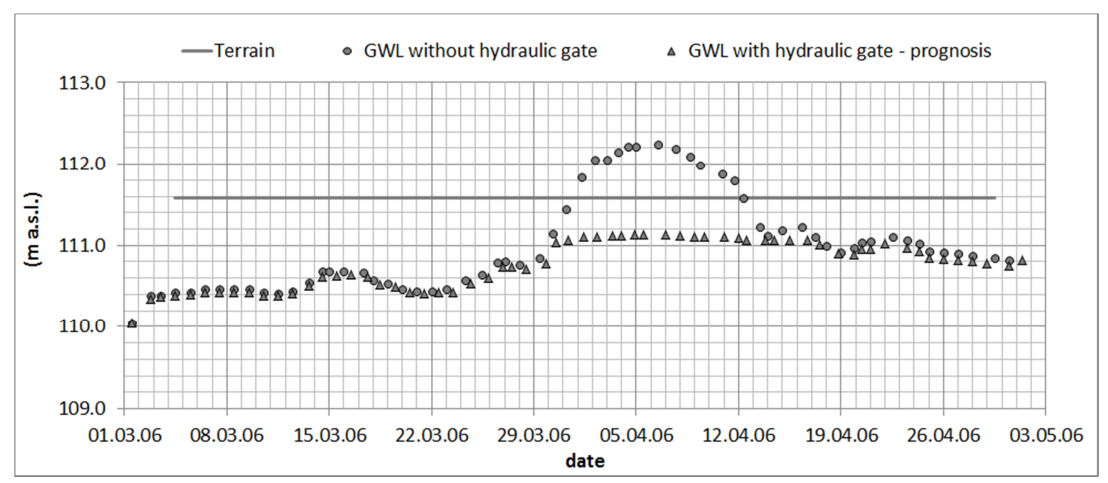

Fig. 6. Course of simulated piezometric groundwater levels in the observation well OW1-10 (GWL: groundwater level)

Table III

Designation of the days of groundwater flow modeling

\begin{tabular}{|l|l|l|l|l|l|}
\hline Day & Date & Remark & Day & Date & Remark \\
\hline 10 & 10.03 .2006 & Relatively steady state & 40 & 09.04 .2006 & Recession \\
26 & 26.03 .2006 & Beginning of flood wave & 43 & 12.04 .2006 & Recession \\
31 & 31.03 .2006 & Rise in the flood wave & 48 & 17.04 .2006 & Steady state \\
35 & 04.04 .2006 & $\begin{array}{l}\text { Culmination of flood } \\
\text { wave }\end{array}$ & 60 & 29.04 .2006 & $\begin{array}{l}\text { End of flood } \\
\text { wave }\end{array}$ \\
\hline
\end{tabular}

\section{Conclusions}

The planned flood protection measure will have a meaning, in particular, in the first stage of implementation of the project, if the area along the Klatov branch will be protected during flood wave. The mathematical modeling of the transient groundwater 
flow by the finite element method proved that increase in the height of the dike on the right-side of the Little Danube to $114.00 \mathrm{~m}$ a.s.l. along with construction of suspended underground wall (implementation of stage II and III) will have a positive impact on the course of piezometric head in the adjacent area of interest during normal flow in the Little Danube. However, there is a little change in the piezometric head in the very narrow strip along the southeast of the dike.

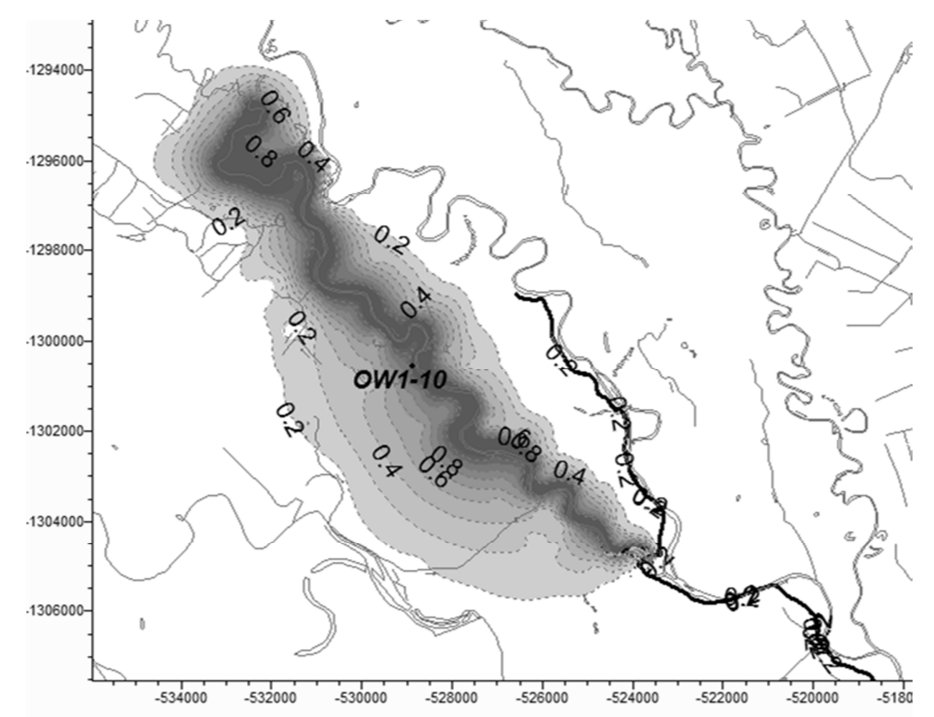

Fig. 7. Course of differences of piezometric groundwater levels on $35^{\text {th }}$ day of simulation and observation well OW1-10 marking

\section{Acknowledgements}

The contribution was developed within the frame and based on the financial support of the APVV-15-0489 project 'Analysis of droughts by multi-criterial statistical methods and data mining from the viewpoint of preventive structures in a landscape as well as under contract No. APVV-16-0278 project 'Use of hydromelioration structures for mitigation of the negative extreme hydrological phenomena effects and their impacts on the quality of water bodies in agricultural landscapes'.

The paper was also developed within the frame of and based on the financial support of the VEGA 1/0800/17 project 'Optimization of the flood protection of municipalities in river basin of mountain streams'.

\section{Open Access statement}

This is an open-access article distributed under the terms of the Creative Commons Attribution-NonCommercial 4.0 International License (https://creativecommons.org/ 
licenses/by-nc/4.0/), which permits unrestricted use, distribution, and reproduction in any medium for non-commercial purposes, provided the original author and source are credited, a link to the CC License is provided, and changes - if any - are indicated.

\section{References}

[1] Frankovský P. Improving the safety of the territory against the backflow of the Little Danube and Klátov River branch from Váh River, $1^{\text {st }}$ phase (in Slovak), Bratislava, 2017.

[2] Korytárová J., Šlezingr M., Uhmannová H. Determination of potential damage to representatives of real estate property in areas afflicted by flooding, Journal of Hydrology and Hydromechanics, Vol. 55, No. 4, 2007, pp. 282-285.

[3] Bednárová E., Škvarka J. Grambličková D. Geotechnical groundwater protection system, Proceedings of the 17th International Multidisciplinary Scientific GeoConference, Albena, Bulgaria, 29 June - 5 July 2017, Vol. 17, No. 12, 2017, pp. 373-380.

[4] Haskoning R. Triwaco groundwater modeling software, TRIWACO User's Manual, The Netherlands, 2004.

[5] Karay G., Szilágyi M., Hajnal G. Determination of the transmissivity of a karstified aquifer from mine dewatering data, Pollack Periodica, Vol. 12, No. 2, 2016, pp. 117-128.

[6] Khosravi K., Shahabi H., Pham B. T., Adamowski J., Shirzadi A., Pradhan B., Dou J., Ly H. B., Gróf G., Ho H. L., Hong H., Chapi K., Parakash C. A comparative assessment of flood susceptibility modeling using multi-criteria decision-making analysis and machine learning methods, Journal of Hydrology, Vol. 573, 2019, pp. 311-323.

[7] Julínek T. Assessing stream water quality influenced by storm overflows from sewers, Pollack Periodica, Vol. 12, No. 2, 2017, pp. 117-128.

[8] Kullman E. Groundwater 2016, Hydrological Yearbook (in Slovak), Bratislava, 2017.

[9] Mišík M., Stoklasa M., Kučera M. Closure structure with pump station on Little Danube and Kolárov River Branch- hydrodynamic modeling for initial study, Final Report under Contract No. 1779/2017-BA (in Slovak), Bratislava, 2018.

[10] Pristaš J., Horniš J., Halouzka R., Maglay J., Konečný V., Lexa J., Nagy A., Vass D., Vozár J. Surface geological map of the Danube region, 1:50 000 (DANREG), Archive ŠGÚDŠ, 1992.

[11] Šulek P., Kinczer T. Expert control system of shipping operation on the Gabcikovo project, Pollack Periodica, Vol. 14, No. 1, 2019, pp. 139-150.

[12] Tall A., Kandra B., Gomboš, M., Pavelková D. The influence of soil texture on the course of volume changes of soil, Soil and Water Research, Vol. 14, No. 2, 2019, pp. 57-66.

[13] Dušek P., Velísková Y. Comparison of the modflow modules for the simulation of the river type boundary condition, Pollack Periodica, Vol. 12, No. 3, 2017, pp. 3-13.

[14] Kminiaková K., Kminiak M., Porubský M. Improving the safety of the territory against the backflow of the Little Danube and Klátov River branch from Váh River, $1^{\text {st }}$ phase- Closure Structure (in Slovak), Report under Contract No. 814/2017-BA, Bratislava, 2017.

[15] Improving the safety of the territory against the backflow of the Little Danube and Klátov River branch from Váh River, ENPRO Consult LLC, (in Slovak), 2012.

[16] Šoltész A., Baroková D. Improving the safety of the territory against the backflow of the Little Danube and Klátov River branch from Váh River, phase I, II, II- Numerical Analysis and prognosis of groundwater flow, Final Report under Contract No. 1358/2018-BA (in Slovak), Bratislava, 2018. 